\title{
PENINGKATAN KUALITAS SUMBER DAYA MANUSIA BERBASIS MASYARAKAT UNTUK MENGATASI MASALAH PENGANGGURAN
}

\author{
Oleh: Bagja Waluya*)
}

\begin{abstract}
Abstrak
Tingginya tingkat pengangguran di Indonesia disebabkan oleh banyak faktor terutama terletak pada kualitas sumber daya manusianya. Salah satu aspek yang berhubungan dengan sumber daya manusia adalah tingkat pendidikan dan keterampilan yang dimiliki masyarakat Indonesia masih rendah juga akibat tidak relevannya pendidikan yang ditamatkan dan keterampilan yang dimiliki pencari kerja dengan tuntutan lapangan kerja.

Urgensi pengentasan pengangguran didasarkan pada beberapa pertimbangan dan kecenderungan yang menyangkut kesejahteraan masyarakat, pertumbuhan ekonomi, stabilitas politik dan keamanan serta tuntutan dan kebutuhan pasar dunia dalam arus globalisasi.

Berbagai program telah banyak dilakukan dalam upaya meningkatkan sumber daya manusia Indonesia sehingga masalah penggangguran dapat diminimalisasi. Salah satunya adalah melalui peningkatan kualitas sumber daya manusia berbasis peran serta masyarakat yang dinilai penting, selain karena terbatasnya kemampuan pemerintah dalam mendanai pembangunan kualitas sumber daya manusia, juga karena hakikat pendidikan adalah emansipatoris, yang bermakna partisipatoris dalam gerakan memberdayakan manusia.

Upaya-upaya pemberdayaan masyarakat dalam meningkatkan sumber daya manusia guna mengatasi pengangguran adalah dengan melalui pelatihan yang berdasarkan kompetensi yang dibutuhkan, memberdayakan sanggar-sanggar kegiatan belajar yang ada dengan berbagai keterampilan ekonomi produktif, meningkatkan hubungan antara lembaga pendidikan dan industri sehingga relevansi pendidikan dapat ditingkatkan, memperkuat landasan kultural pendidikan sebagai terapi budaya, dan mendorong pertumbuhan usaha kecil dan menengah yang tangguh, serta membangkitkan karsa di tengah-tengah masyarakat.
\end{abstract}

Kata kunci: Kualitas SDM, berbasis masyarakat, masalah pengagguran.

\section{Pendahuluan}

Masalah pengangguran merupakan salah satu persoalan nasional yang sampai saat ini belum berhasil terpecahkan secara oftimal dan diperkirakan akan tetap mewarnai ketenagakerjaan Indonesia hingga beberapa waktu mendatang. Bahkan masalah yang satu ini menjadi salah satu program andalan para calon presiden untuk mendapatkan simpati rakyat. Mengentaskan pengangguran memang merupakan program strategis dalam rangka meningkatkan kesejahteraan masyarakat sekaligus pertumbuhan ekonomi negara, bahkan masalah

*) Bagja Waluya, S.Pd., adalah Dosen Jurusan Pendidikan Geografi FPIPS-UPI. 
ketenagakerjaan secara langsung maupun tidak berkaitan dengan masalah-masalah lainnya termasuk kemiskinan, ketidakmerataan pendapatan, urbanisasi, stabilitas politik dan keamanan. Melalui kesejahteraanlah cita-cita bangsa dan negara yang aman dan damai bisa tercapai.

Banyak faktor yang mempengaruhi tingginya angka pengangguran di Indonesia. Latarbelakang tingkat pendidikan masyarakat yang masih rendah selalu menjadi alasan utamanya. Pedahal, selama 10 tahun terakhir, telah terjadi pergeseran dalam pengangguran terbuka, yaitu dari pengangguran berpendidikan rendah ke pengangguran berpendidikan tinggi. Sebagaimana telah dilakukan studi oleh Depnakertrans yang mengemukakan angka bahwa penganggur terbuka berpendidikan akademi atau D3 pada tahun 2000 tercatat sebesar 8,61\% dari angkatan kerja jenjang pendidikan tersebut telah meningkat menjadi $11,22 \%$ pada tahun 2002. Sementara itu, penganggur terbuka berpendidikan D3 pada tahun 2000 tercatat sebesar 12, $03 \%$ menurun menjadi $10,83 \%$ pada tahun 2001 .

Rendahnya tingkat pendidikan dan keterampilan masyarakat kita sangat berdampak pada rendahnya kualitas tenaga kerja yang dimiliki. Fenomena tersebut dapat dilihat pada pasaran tenaga kerja Indonesia yang pergi ke luar negeri yang sampai saat ini permasalahannya belum pernah terselesaikan. Pedahal, menurut survei keberadaan TKI telah menyumbangkan devisa negara tahun 2009 sebesar 90 triliun atau 10\% dari APBN. Menurut Mantra (1996) posisi-posisi penting tenaga kerja di negara pengimpor tenaga kerja seperti di negara-negara asia barat daya telah diisi oleh tenaga-tenaga trampil dari Korea Selatan, Pakistan, India dan Jepang. Mengingat kualitas tenaga kerja Indonesia masih rendah, maka tidaklah mengherankan apabila sebagian besar dari mereka terdiri atas perempuan dan bekerja sebagai pramuwisma dimana di mata internasional posisi seperti itu sangatlah tidak prestisius.

Sejak era 1990-an, sebenarnya pemerintah juga telah menyadari, bahkan pada pembangunan jangka panjang tahap II, telah dicanangkan pembangunan kualitas sumberdaya manusia dengan segala matranya, baik yang menyangkut kualitas pribadi, anggota keluarga, anggot. Masyarakat, warga negara dan himpunan komunitas. Sebagai realisasi dari program tersebut, maka seluruh gerak pembangunan harus mengacu pada peningkatan kualitas sumberdaya manusia sesuai dengan UU No. 10 tahun 1992 tentang Perkembangan Kependudukan dan Pembangunan Keluarga Sejahtera.

Bertolak dari latar belakang tersebut, adalah sangat penting dan segera untuk dicarikan pemecahannya. Berbagai unsur, baik pemerintah, pengusaha/swasta, akademisi, dan masyarakat harus turut serta memikirkannya. Karena itu artikel ini akan dibahas tentang Peningkatan Kualitas Sumber Daya Manusia Berbasis Peran Serta Masyarakat Guna Mengatasi Pengangguran.

Pemilihan judul ini dinilai penting karena beberapa alasan berikut. Kesatu, pertumbuhan ekonomi yang terus membaik namun tidak diikuti penurunan angka kemiskinan dan jumlah pengangguran mengimplikasikan adanya ketimpangan pendapatan dan ketidaksamaan kesempatan dalam menikmati pembangunan dan hasil-hasilnya. Kesenjangan bisa terjadi akibat terbatasnya akses, yang antara lain

*) Bagja Waluya, S.Pd., adalah Dosen Jurusan Pendidikan Geografi FPIPS-UPI. 
disebabkan rendahnya keterampilan yang dimiliki guna terlibat dalam keseluruhan proses pembangunan.

Kedua, masalah pengangguran penting didekati dari sisi peningkatan kualitas sumber daya manusia karena terkait fakta bahwa pengangguran terjadi bukan semata-mata terbatasnya lapangan pekerjaan tetapi juga akibat tidak relevannya pendidikan yang ditamatkan dan keterampilan yang dimiliki pencari kerja dengan tuntutan lapangan kerja (Depdiknas, 2006).

Ketiga, masalah pengangguran harus mendapat perhatian serius karena kesenjangan sosial yang muncul akibat pengangguran dan terbatasnya akses terhadap pembangunan dan hasil-hasilnya dapat mengikis rasa, paham, dan semangat wawasan kebangsaan (Jusuf, 2007). Bila tidak ditangani, pengikisan wawasan kebangsaan bisa mengancam integritas wilayah dan integrasi bangsa. Lebih-lebih Indonesia secara geopolitik amat strategis.

Keempat, peningkatan kualitas sumber daya manusia berbasis peran serta masyarakat dinilai penting selain karena terbatasnya kemampuan pemerintah dalam mendanai pembangunan kualitas sumber daya manusia, juga karena hakikat pendidikan adalah emansipatoris (Poespowardojo, 2007), yang bermakna partisipatoris dalam gerakan memberdayakan manusia. Hal ini pun sejalan dengan paradigma pembangunan pendidikan yang diletakkan pemerintah, yakni pembangunan pendidikan yang bersoko pada keluarga, masyarakat, dan pemerintah.

Masalah pengangguran yang antara lain disebabkan rendahnya kualitas sumber daya manusia dihadapkan kepada kecenderungan lingkungan strategis pada tataran global dan paradigma pembangunan nasional yang menekankan partisipasi dan kemandirian menuntut perhatian semua pihak. Partisipasi masyarakat dalam memperluas pemerataan dan peningkatan kualitas pendidikan sebagai salah satu usaha peningkatan kualitas sumber daya manusia amat dibutuhkan.

\section{Kecenderungan Globalisasi dan Urgensi Peningkatan Sumber Daya Manusia}

Peningkatan kualitas sumber daya manusia dalam mengatasi pengangguran secara teoretis dan empirik amat menarik karena terkait dengan visi organisasi modern dan kecenderungan lingkungan strategis pada tataran global.

Visi organisasi modern menempatkan manusia sebagai faktor strategis dalam semua kegiatan organisasi. Dikatakan demikian karena apapun bentuk dan tujuannya, organisasi dibuat berdasarkan visi untuk kepentingan manusia, dan dalam pelaksanaan misinya bergantung kepada kemampuan sumber daya manusia dalam menata dan memobilisasi semua sumber daya yang tersedia (Drucker, 1988). Dengan kata lain, peningkatan kualitas sumber daya manusia mutlak dilakukan semua organisasi - termasuk oleh pemerintah daerah - agar visi organisasi dapat dicapai.

Selain terkait dengan penekanan terhadap faktor manusia dalam organisasi, peningkatan kualitas sumber daya manusia kini semakin penting dilakukan setiap

*) Bagja Waluya, S.Pd., adalah Dosen Jurusan Pendidikan Geografi FPIPS-UPI. 
organisasi di manapun ia beroperasi karena beberapa kecenderungan global berikut.

a. Berbagai kemajuan teknologi yang berlangsung sangat cepat pada 10-20 tahun terakhir, terutama dalam telekomunikasi. Kemajuan teknologi yang amat pesat dan pengaruhnya terhadap kehidupan manusia yang amat besar menyebabkan ketergantungan manusia pada suatu hasil teknologi semakin besar. Kecenderungan ini amat tampak dari cara orang memahami pengertian teknologi. Bila pada 1967 teknologi cukup didefinisikan sebagai benda, sebuah objek, bahan dan wujud yang jelas-jelas berbeda dengan manusia, maka pada 1987, teknologi telah didefinisikan sebagai sesuatu yang "erat berkaitan dengan kehidupan, masyarakat, dan lingkungan" (Naisbitt, 2001:46). Artinya, teknologi tidak hampa, bukan entitas yang berdiri sendiri tanpa makna, yang sampai derajat tertentu, para penggunalah yang menentukan kebermaknaan sebuah teknologi.

b. Pengaruh globalisasi perusahaan manufaktur Amerika Serikat memanfaatkan buruh murah di negara-negara berkembang, persaingan yang semakin mendunia, produksi manufaktur multinasionsl semakin banyak ditemui di pasaran lokal. Beragam merk produk perusahaan multinasional mudah ditemui, mulai dari merk barang kebutuhan sehari-hari hingga barang-barang mewah.

c. Pengaruh deregulasi atau berkurangnya pengaturan harga, entry tariff oleh pemerintah, proteksi dan monopoli yang semakin berkurang menyebabkan munculnya berbagai perusahaan baru dalam bidang telekomunikasi, penerbangan, bank yang beroperasi dengan biaya yang relatif lebih rendah. Hal ini menyebabkan daya hidup perusahaan sangat bergantung kepada efisiensi dan kompetisi dalam memuaskan pelanggannya.

d. Demografi tenaga kerja global yang berubah, mengarah kepada workforce diversity, diskriminasi tenaga kerja yang semakin longgar, bertambahnya tenaga usia tua dan tenaga kerja wanita. Data yang dihimpun European Parliament Working Document (1980/1981) mengungkapkan kecenderungan meningkatnya jumlah pekerja wanita. Bila perbandingan pekerja wanita dengan laki-laki mencapai 1:5 pada tahun 1947; 2:5 pada tahun 1970; maka kini diperkirakan $42 \%$ pekerja di negara maju adalah wanita.

e. Perubahan sistem sosio-politik seperti Rusia yang menjadi kapitalis, RRT yang menjadi negara industri, berdirinya aosiasi-asosiasi regional (EU, NAFTA, APEC, dan lain-lain) yang antara lain bertujuan mewujudkan kerjasama ekonomi, liberalisasi dan deregulasi perdagangan. Kecenderungan ini telah memasukkan Indonesia menjadi bagian dari AFTA (ASEAN Free Trade Area) dan AFLA (ASEAN Free Trade Labour) tahun 2003. Padahal kualitas sumber daya manusia Indonesia masih jauh tertinggal dibanding bangsa lain.

Pergeseran-pergeseran tersebut berdampak kepada semakin banyaknya pilihan bagi konsumen, terjadinya merger, joint-venture, dan bahkan divestasi dan menutup usaha, siklus hidup produk menjadi lebih pendek dan terjadi fragmentasi pasar. Fenomena-fenomena tersebut menimbulkan ketidakpastian, yang membuat

*) Bagja Waluya, S.Pd., adalah Dosen Jurusan Pendidikan Geografi FPIPS-UPI. 
setiap perusahaan berlomba mencari informasi terbaru yang diyakini dapat mengurangi ketidakpastian.

Ada dua strategi yang diambil para manajer dalam merespon kecenderungankecenderungan global tadi (Tarumingkeng, 2000: 3), yakni mengubah struktur organisasi dan perampingan personalian (downsizing). Organisasi yang lebih datar (flat organization) kini menjadi norma baru. Organisasi piramidal dengan 7-10 lapis kini mulai di-“datar"-kan menjadi hanya 3-4 lapis (AT\&T dan GE dari 12 kini menjadi hanya 6 lapis atau kurang). Bentuk piramidal kini bahkan dianggap kuno, tradisional, out of style, "rantai komando" semakin tidak diikuti, tetapi dengan jaminan adanya operating procedurs yang jelas.

Perampingan personalia (downsizing) dan kecenderungan bekerja dalam team yang lebih mendasarkan kerjanya kepada proses, bukan fungsi spesialisasi, semakin menonjol. Istilah pemberdayaan (empowering) yang kini digunakan dalam banyak aspek, juga merambah manajemen SDM. Pemberdayaan tenaga kerja (employee empowerment) dilaksanakan terutama bagi front line employees (seperti front desk clerks) untuk memberikan kepuasan maksimum kepada pelanggan.

Manajemen sekarang telah banyak berubah dari keadaan 20 atau 30 tahun lalu, dimana human capital menggantikan mesin-mesin sebagai basis keberhasilan kebanyakan perusahaan. Drucker (1998) mengemukakan bahwa tantangan bagi para manajer sekarang adalah kenyataan bahwa tenaga kerja cenderung sulit diatur seperti tenaga kerja generasi yang lalu. Titik berat pekerjaan kini bergerak sangat cepat dari tenaga manual dan clerical ke knowledge-worker yang menolak menerima perintah ("komando") seperti yang digunakan dalam organisasi militer, cara yang diadopsi oleh dunia bisnis 100 tahun yang lalu.

Kecenderungan yang kini berlangsung menuntut angkatan kerja memiliki pengetahuan baru yang sesuai dengan dinamika perubahan yang tengah berlangsung. Tenaga kerja di sektor jasa di negara maju (kini sekitar 70\%) dari tahun ke tahun semakin meningkat, dan tenaga paruh waktu juga semakin meningkat. Pola yang berubah ini menuntut "pengetahuan" baru dan cara penanganan yang baru. Human capital yang mengacu kepada pengetahuan, pendidikan, latihan, keahlian tenaga kerja perusahaan kini menjadi semakin penting dibandingkan dengan dekade sebelumnya.

Dalam kategori workforce diversity, sedang berlangsung peningkatan umur manusia yang berdampak kepada meningkatnya usia lanjut yang memasuki angkatan kerja. Di AS sejak tahun1979 telah terjadi peningkatan umur median dari 34,7 tahun ke 37,8 di tahun 1995 dan menjadi 40,5 di tahun 2005 (European Parliament Working Document, 1980/1981).

Kecenderungan-kecenderungan di atas sebagian telah memperlihatkan dampaknya terhadap sumber daya manusia yang dituntut beberapa perusahaan di Indonesia, yang antara lain tampak dalam tingginya permintaan terhadap tenaga kerja yang handal dalam bidang teknologi informasi (TI). Dalam tiga tahun terakhir saja terdapat lebih kurang 200 perusahaan yang bergerak di bidang TI. Lowongan kerja di bidang TI pun mendominasi space iklan yang ditawarkan media cetak dan elektronik. Menurut Auditsi \{sebuah lembaga penempatan tenaga kerja TI di

*) Bagja Waluya, S.Pd., adalah Dosen Jurusan Pendidikan Geografi FPIPS-UPI. 
Jakarta) pada tahun 1999 saja kebutuhan tenaga kerja TI mencapai 20\% dari total kebutuhan tenaga kerja.

Permintaan akan profesional TI bukan saja datang dari dalam negeri, tetapi juga datang dari luar negeri. Bila tidak diantisipasi, permintaan tadi akan segera dipenuhi oleh tenaga-tenaga profesional dari India dan Srilanka, yang terus memacu pembangunan infrastruktur telekomunikasi dan mengembangkan aplikasiaplikasi TI.

Bagi organisasi yang beroperasi di Indonesia, manajemen sumber daya manusia menjadi penting, baik karena visi pembangunan nasional maupun karena alasan globalisasi. Visi pembangunan nasional diarahkan bagi terwujudnya masyarakat Indonesia yang damai, demokratis, berkeadilan, berdaya saing, maju dan sejahtera, yang didukung oleh kualitas manusia Indonesia yang mandiri, beriman, bertaqwa, berakhlak mulia, cinta tanah air, berkesadaran hukum dan lingkungan, menguasai ilmu pengetahuan dan teknologi, memiliki etos kerja yang tinggi serta berdisiplin.

Selain terkait dengan visi pembangunan nasional, arti penting kualitas SDM bagi manajer Indonesia terkait pula dengan posisi geoekonomi politik Indonesia, yang berada di jalur lalu lintas internasional, jumlah penduduk besar, namun dengan kualitas sumber daya yang masih terbatas.

Data tentang Human Development Index (HDI) yang dikeluarkan United Nations for Development Program (UNDP) menunjukkan peringkat kualitas SDM Indonesia tahun 2000 yang berada pada urutan 109, atau menurun empat peringkat dari tahun sebelumnya. HDI Indonesia pada tahun 2000 ini sedikit lebih baik dibandingkan Vietnam yang berada di urutan 110, namun lebih buruk dibandingkan Singapura (peringkat 22), Brunei (25), Malaysia (56), Thailand (67), dan Philipina (berada di urutan 77).

Bila masalah sumber daya manusia Indonesia tidak menjadi perhatian serius, tidak mustahil Indonesia hanya akan menjadi serbuan produk global dan "kantong" tenaga kerja murahan. Dalam konteks inilah agenda peningkatan kualitas sumber daya manusia menjadi kebutuhan mendesak bila Indonesia tidak ingin menjadi bangsa "kuli".

\section{Penerapan Manajemen Sumber Daya Manusia (MSDM) di Lingkungan Pemerintahan Daerah}

Peningkatan kualitas sumber daya manusia di daerah menuntut pemerintahan daerah menerapkan asas-asas manajemen sumber daya manusia (MSDM). Urgensi penerapan MSDM, secara teoretis dilandasi oleh hasil riset beberapa komisi yang dibentuk oleh banyak pemerintahan dalam mengukur performance pemerintahannya, baik pemerintah pusat maupun pemerintah daerah (local government). Sedangkan secara praktis, pentingnya penerapan MSDM di Daerah terkait dengan pelimpahan sejumlah wewenang dari Pemerintah kepada Daerah dalam kerangka otonomi.

Hasil penelitian sebuah komisi di bawah pimpinan Sir John Maud (1967) mengungkapkan bahwa manajemen pada banyak pemerintahan lokal menjadi tidak

*) Bagja Waluya, S.Pd., adalah Dosen Jurusan Pendidikan Geografi FPIPS-UPI. 
efisien karena begitu banyaknya komisi dan departemen, yang masing-masing berkaitan dengan aspek khusus bidang pemerintahan, terlalu berorientasi ke dalam (inward looking), terlalu tersentralisasi pada detil-detil yang sangat khusus, dikoordinasikan secara kurang efisien dan secara konsekuen gagal melihat kebutuhan umum orang-orang yang ada di wilayah kewenangannya.

Pemecahan administrasi pemerintahan ke dalam komisi yang terpisah secara berlebihan telah menyebabkan anggota komisi (dinas, badan, atau kantor) yang terpilih yang berkonsentrasi terhadap masalah-masalah administrasi secara detil. Terlalu sering mereka malihat hal-hal detil dimana pejabat pemerintahan lokal secara teori harus menggarapnya dan mereka amat kurang menaruh perhatian terhadap kepentingan umum (Bourn, 1979).

Untuk mengatasi defisiensi, komisi tersebut mengajukan sebuah introduksi tentang dewan manajemen dengan keaanggotaan yang dipilih yang bertanggung jawab dalam memformulasikan tujuan-tujuan kebijakan, mengambil keputusan eksekutif serta mengkoordinasikan dan mengawasi pekerjaan pemerintah. Introduksi tentang dewan manajemen akan membantu mengurangi jumlah komisi di dalam masing-masing wewenang, dan introduksi tadi menyarankan agar komisi yang ada (yang tidak dihilangkan) harus berkonsentrasi terhadap fungsi-fungsi deliberatif dan representatif, membuat rekomendasi kepada dewan manajemen tantang tujuan kebijakan, cara untuk mencapainya dan rekomendasi tentang laporan kemajuan perencanaan dan program. Secara umum dapat dikatakan bahwa mereka tidak memiliki kekuasaan eksekutif sejak kewenangannya dijalankan oleh dewan manajemen. Lebih dari itu, garis yang tegas harus ditarik antara aktivitas anggotaanggota yang dipilih dan pegawai-pegawai pemerintahan lokal. Komisi Maud mengajukan bahwa dewan manajemen akan dibantu oleh seorang kepala kantor yang baru yang menyelenggarakan kewenangan atau sebagai kepala kantor dan bertanggung jawab atas efisiensi dan koordinasi. Semua administrasi rutin secara detil didelegasikan kepada karyawan/staf kantor.

Asumsi di atas, terkait dengan dua hal, yakni (1) kontribusi pengembangan SDM bagi keberhasilan organisasi, dan (2) hakikat desentralisasi kebijakan yang memungkinkan terjadinya proses pembelajaran bagi tumbuhnya inisiatif dan kreativitas Daerah dalam menggali potensi dan memanfaatkan peluang yang ada.

\section{a. Kontribusi Pengembangan SDM}

Kontribusi pengembangan SDM bagi pencapaian tujuan organisasi telah mendapat tekanan beberapa ahli manajemen, khususnya manajemen organisasi. Para teoretisi manajemen organisasi meyakini bahwa pengembangan SDM secara signifikan akan mempengaruhi kinerja organisasional hanya jika program tersebut dilakukan melalui proses yang benar secara akademis. Konsep dimaksud harus diarahkan pada peningkatan skill, knowledge, dan ability, sebagai refleksi atas penguasaan kompetensi tertentu melalui program pelatihan. Hal ini relevan dengan kecenderungan global dalam bidang pelatihan dengan penerapan konsep Competency-Based Training (SBT), sebuah konsep pelatihan yang mengarahkan pesertanya pada penguasaan keahlian tertentu.

*) Bagja Waluya, S.Pd., adalah Dosen Jurusan Pendidikan Geografi FPIPS-UPI. 
Karakteristik utama pengembangan SDM berbasis kompetensi adalah menghindari proses pelatihan yang hanya memenuhi formalitas dengan pemberian sertifikat kepada pesertanya. Oleh karena itu, langkah pertama yang dilakukan dalam mengaplikasikan CBT adalah melakukan training needs assessment sebagai sasaran yang ingin dicapai melalui pelatihan. Program pelatihan dirancang berdasarkan analisis atas kebutuhan-kebutuhan organisasi.

Beberapa negara tercatat telah menerapkan konsep CBT dalam usaha memacu pembangunan daerahnya. Satu diantaranya adalah Australia yang berhasil memanfaatkan sumber daya yang dimilikinya di atas prinsip a clever country, a capable country (Irianto, 2001). Manfaat penerapan konsep CBT sangat dirasakan, dengan keterbatasan yang dimiliki Australia, negara ini dapat mengelola kekayaan alamnya secara efisien dengan dukungan aparat pemerintah yang berkompeten.

Berdasarkan pengalaman beberapa negara, keberhasilan penerapan CBT ditentukan pula oleh sistem hukum kepegawaian yang bersifat achievement oriented, suatu sistem kepegawaian yang tidak semata-mata mensyaratkan kepemilikan ijazah formal untuk menduduki suatu jabatan dan perkembangan karier. Seseorang dapat menduduki suatu jabatan hanya jika yang bersangkutan telah menguasai standar kompetensi yang ditetapkan.

\section{b. Desentralisasi Kebijakan dan Pengembangan SDM}

Beberapa permasalahan yang muncul menyertai penerapan desentralisasi kebijakan dalam kerangka otonomi daerah mengisyaratkan bahwa keberhasilan pembangunan dalam konteks otonomi daerah bukan semata-mata ditentukan oleh seberapa besar kewenangan Daerah, melainkan ditentukan pula oleh kualifikasi aparatur di Daerah dalam mengelola kekayaan alam dan sosial di Daerah. Hal inilah yang menuntut penerapan manajemen strategik, karena aparatur yang tersedia belum sepenuhnya dapat dikategorikan sebagai sumber daya manusia karena banyak diantaranya belum memiliki kualifikasi yang disyaratkan, baik pengetahuan, sikap, keterampilan, maupun komitmen pada penyelenggaraan tugas yang melekat pada jabatan yang disandangnya.

Hingga kini, pemahaman Daerah tentang manajemen sumber daya manusia masih identik dengan pelatihan, penataran, atau beragam bentuk kursus singkat, sehingga pegawai yang sudah dinyatakan lulus dalam program tersebut dikategorikan sebagai pegawai dengan kualitas sumber daya yang memadai. Di sinilah letak persoalannya, latihan pra jabatan misalnya (sebagai pelatihan yang diterima setiap calon pegawai negeri) masih didominasi oleh program-program yang terkesan hanya menghabiskan anggaran, dengan materi yang tidak spesifik dan tidak mengarah pada penguasaan kecakapan khusus yang dibutuhkan.

Selain masih kuatnya sifat formalistik, beragam pelatihan pegawai yang diterapkan di tanah air umumnya tidak didahului oleh penilaian atas kebutuhan, di samping tidak memiliki model yang spesifik, sehingga keberhasilan penyelenggaraannya sulit dipastikan. Dengan kata lain, tidak ada kejelasan menyangkut hubungan antara substansi program, kecakapan yang telah dimiliki dan yang dibutuhkan peserta, kualifikasi pelatih, dan tujuan yang hendak dicapai.

*) Bagja Waluya, S.Pd., adalah Dosen Jurusan Pendidikan Geografi FPIPS-UPI. 
Keadaan ini diperparah oleh mentalitas feodal yang masih kuat di kalangan birokrasi di tanah air. Mentalitas inilah yang memacu pemalsuan gelar, atau tindakan-tindakan lain yang hanya berorientasi pada perolehan gelar sebagai simbol status tanpa mempedulikan kelaikan akademis.

\section{Peran Serta Masyarakat dalam Peningkatan Kualitas Sumber Daya Manusia Guna Mengatasi Pengangguran}

Kontribusi pendidikan dalam meningkatkan kualitas sumber daya manusia sudah menjadi keniscayaan. Sayangnya, beragam persoalan masih melilit dunia pendidikan sehingga hasilnya kontraproduktif bagi pengentasan masalah pengangguran. Selain itu, peran serta masyarakat dalam memajukan dunia pendidikan perlu terus ditingkatkan, karena secara fundamental pendidikan dilakukan bersama-sama oleh keluarga, masyarakat, dan pemerintah.

Pendidikan yang sejatinya menyiapkan peserta didik yang bisa hidup mandiri malah terjebak kepada penciptaan ketergantungan. Para lulusan bukan hanya gagal menciptakan lapangan kerja, tetapi juga tidak sanggup memenuhi tuntutan dunia kerja yang ada antara lain karena tidak memiliki kompetensi yang dibutuhkan (mismatch).

Manajemen pendidikan yang terjebak pada kekakuan birokrasi dan proses pembelajaran yang masih terbatas pada pemberian pengetahun makin menjauhkan mutu lulusan pendidikan dari tuntutan dunia kerja. Kesenjangan ini muncul antara lain karena lembaga pendidikan belum menyiapkan peserta didik yang memiliki kompetensi yang dibutuhkan dunia kerja.

Fakta bahwa jenjang pendidikan yang ditamatkan berbanding terbalik dengan kemandirian dan kemampuan berwirausaha mengindikasikan dua hal. Pertama, pendidikan persekolahan turut menyumbang dan terus memicu tingginya angka pengangguran. Kedua, sebagian besar anggota masyarakat yang menjalankan usaha mandiri dan rumah tangga adalah lulusan pendidikan dasar dan menengah. Bahkan, jumlah mereka yang tidak tamat sekolah lebih besar dibanding lulusan perguruan tinggi yang mampu mengelola usaha mandiri dan rumah tangga. Dengan demikian, usaha kecil dan menengah yang diklaim sebagai soko guru perekonomian bangsa digerakkan oleh warga masyarakat yang hanya menamatkan jenjang pendidikan dasar dan menengah.

Meningkatnya jumlah penganggur akibat kegagalan lembaga pendidikan dalam mengantisipasi perkembangan dan tuntutan dunia kerja diyakini akan makin melemahkan daya saing bangsa. Padahal, kompetisi pada tingkat global bukan lagi sekedar wacana.

Terkait dengan fungsi pokok pemerintah daerah dalam pemberdayaan politik masyarakat (BS Sismenas, 2007: 4) dalam meningkatkan sumber daya manusia guna mengatasi pengangguran upaya-upaya berikut perlu dilakukan.

1) Melakukan berbagai pelatihan/kurus berdasarkan kompetensi yang dibutuhkan, didahului oleh training needs assessment dengan mensinergikan program yang dirancang dinas pendidikan, organisasi profesi, kalangan industri, dan stakeholders pendidikan yang lain.

*) Bagja Waluya, S.Pd., adalah Dosen Jurusan Pendidikan Geografi FPIPS-UPI. 
2) Memberdayakan sanggar-sanggar kegiatan belajar yang dikelola Pusat Kegiatan Belajar Masyarakat dengan memperluas cakupan program bukan hanya baca, tulis, dan hitung (calistung) dengan berbagai keterampilan ekonomi produktif.

3) Meningkatkan hubungan antara lembaga pendidikan dan industri sehingga relevansi pendidikan dapat ditingkatkan. Komtmen Pemda Jabar untuk menjadi pusat perkembangan sekolah kejuruan terus didorong dengan peningkatan penguasaan kecakapan hidup (life skills) di kalangan siswa, sehingga mereka bisa menjadi enterpreneur.

4) Memperkuat landasan kultural pendidikan sebagai terapi budaya, yang didasarkan atas komitmen untuk (a) memelihara eksistensi negara dan bangsa; (b) memelihara integrasi nasional, yakni keutuhan ideologis Pancasila dan UUD 1945, sosial, dan integrasi teritorial; dan (c) melaksanakan pembangunan guna mempercepat recovery melalui penguatan pendidikan karakter baik melalui jalur sekolah, maupun melalui organisasi kemasyarakatan pemuda.

5) Meningkatkan skill, knowledge, dan ability aparatur sehingga dapat mewujudkan fungsinya dalam pemberdayaan politik masyarakat, mendorong pertumbuhan usaha kecil dan menengah yang tangguh, serta membangkitkan karsa di tengah-tengah masyarakat.

\section{Kesimpulan}

Pendidikan yang tidak fungsional dan pelatihan yang tidak menunjang peningkatan kualitas sumber daya manusia hanya akan mengikis kemandirian bangsa dari dalam. Pelemahan kemandirian dan daya saing pada gilirannya makin memicu ketergantungan bangsa terhadap luar negeri dan menghebatnya eksploitasi antarelemen masyarakat di dalam negeri. Dalam skala mikroskofis, eksploitasi terjadi dalam bentuk ketergantungan masyarakat desa terhadap struktur perekonomian kota.

Penerapan prinsip, asumsi, dan pendekatan MSDM di Daerah semakin penting dalam usaha meningkatkan kualitas sumber daya aparatur pemerintah di Daerah. Pengembangan SDM di Daerah sangat erat kaitannya dengan sistem hukum kepegawaian serta model pelatihan dan pengembangan pegawai. Oleh karena itu, diperlukan transformasi dalam model pelatihan dan pengembangan ke arah pelatihan dan pengembangan yang berorientasi pada prestasi dan kebutuhan pelatihan.

Pelatihan dan pengembangan pegawai mengharuskan diawali dengan need assessment. Atas dasar analisis kebutuhan inilah program pelatihan dan pengembangan pegawai disusun. Konsekuensinya, setiap daerah akan memiliki prioritas penekanan yang berbeda. Selain disesuaikan dengan kecakapan yang telah dimiliki pegawai, juga dipengaruhi oleh tantangan yang dihadapi dan budaya kerja yang sudah dan akan dibangun dalam mewujudkan good governance.

*) Bagja Waluya, S.Pd., adalah Dosen Jurusan Pendidikan Geografi FPIPS-UPI. 


\section{Daftar Pustaka}

BS Sismennas, 2007, Implementasi Sismennas dalam Pembangunan Daerah, Jakarta, Lemhanas.

Jusuf, Gani, 2007, Pemantapan Nilai-nilai Wawasan Kebangsaan dalam Menjamin Keutuhan NKRI, Jakarta: Lemhanas.

Poespowardojo, Soerjanto, 2007, Peran Pancasila dalam Pembangunan Nasional, Jakarta: Lemhanas.

Suradinata, Ermaya, 2007, Penerapan Geopolitik Indonesia (Konsepsi Wasantara dalam Menjamin Keutuhan NKRI), Jakarta: Lemhanas.

Drucker, Peter, 1988 The Coming of the New Organization, Harvard Busimess Review, Januari-Februari 1998: p. 45

European Parliament Document, 1980/1981 European Parliament Working Document, London.

Rudy C. Tarumingkeng, 2000 Peran Strategis Manajemen Sumber Daya Manusia, http://www.rudyctripod.com

*) Bagja Waluya, S.Pd., adalah Dosen Jurusan Pendidikan Geografi FPIPS-UPI. 